trong nghiên cứu này mốc phát triển để xác định trẻ chậm nói cũng là dấu hiệu báo động đỏ nguy cơ trẻ rối loạn phổ tự kỷ được khuyến cáo. 3 trẻ có tiền sử được chẩn đoán rối loạn phổ tự kỷ đều có M-CHAT dương tính, kết quả này cũng phản ánh độ đặc hiệu của thang M-CHAT là rất cao, các nghiên cứu khác ghi nhận giá trị này lên đến $99,9 \%$ [4].

\section{KẾT LUÂN}

- Qua sàng lọc 528 trẻ 18-36 tháng tuổi tại 26 trường mầm non bằng thang điểm M-CHAT do giáo viên thực hiện ghi nhận 6,63\% trẻ dương tính, tỷ lệ này phản ánh thang điểm $M$ CHAT do giáo viên mầm non thực hiện có độ nhạy thấp hơn những nghiên cứu khác.

- Trẻ có biểu hiện chậm nói so với tuổi hay bi gia đình và giáo viền nghi ngờ có vấn đề về phát triển có tỷ lệ dương tính cao lần lượt là $41,79 \%$, $78,95 \%$ và $61,82 \%$ và sự khác biệt có ý nghĩa thống kê. Các câu hỏi 3,11,19 trong thang điểm M-CHAT có tỷ lệ dương tính cao nhất lần lượt là $85,71 \%, 80,00 \%, 88,57 \%$.

\section{KIẾN NGH!:}

- Áp dụng sàng lọc trẻ RLPTK bằng thang điểm M-CHAT tại các trường mâm non đặc biệt nhóm trẻ chậm nói so với tuổi hoặc có phụ huynh, giáo viên nghi ngờ về phát triển.

- Tăng cường tập huấn cho giáo viên thực hiện thang điểm M-CHAT, đánh giá độ nhạy độ đặc hiệu của thang điểm khi được áp dụng tại các trường mầm non ở tỉnh Cà Mau

\section{TÀI LIÊU THAM KHẢO}

1. American Psychiatric Association (2013) Diagnostic and Statistical Manual of Mental Disorders $5^{\text {th }}$ Edition, Washington DC, p.50

2. CDC (2020). Basics about Autism Spectrum Disorder (ASD) | NCBDDD | CDC [Internet]. Centers for Disease Control and Prevention. 2020 [cited 2020 Oct 20]. Available from: https://www.cdc.gov/ncbddd/autism/facts.html.

3. World Health Organization (2014). Comprehensive and coordinated efforts for the management of Autism spectrum disorders, World Health Organization.

4. Nguyễn Thị Hương Giang và cộng sự (2010), "Nghiên cứu một số nguy cơ của trẻ tự kỷ từ 18 tháng đến 36 tháng tuổi", Tạp chí y học thực hành, 739(10/2010), Tr.16-18.

5. Phuong Minh Nguyen, Thien Thang Tran (2021), "Clinical characteristics and associated socio-demographic factors of autism spectrum disorder in Vietnamese children", Curr Pediatr Res2021; 25 (1): 308-312

6. Trân Thiện Thẳng (2019), "Khảo sát tỷ lệ trẻ từ 18-36 tháng có biểu hiện rối loạn phổ tự kỷ tại phòng khám bệnh viện nhi đồng cân thơ bằng thang điểm M-CंHAT", Tạp Chí Y Dược Học Cần Tho, 22-25,tr. 293-304.

7. Nguyễn Đức Trí, Trân Diệp Tuấn, (2014), "Nghiên cứu tỷ lê M-CHAT dưởng tính (nguy cơ bi rối loạn phổ tự kỷ): Một khảo sát tại cộng đông trẻ hoc mầm non từ 16-36 tháng trong Quận Ninh Kiêu, thành phố Cần Thơ", Tạp chí nghiên cứu y học TP. Hồ Chí Minh, 18, tr.454-458.

\title{
BÊNNH QUANH RĂNG VÀ MộT SỐ YẾU TỐ LIÊN QUAN Ở TRẺ MẮC HộI CHỨNG THÂ̂N HƯ TIÊN PHÁT
}

\section{Lương Minh Hằng ${ }^{1}$, Tống Minh Sơn ${ }^{1}$, Trần Huy Thịnh², Trần Thị Mỹ Hạnh ${ }^{1}$, Đào Thị Hằng $\mathrm{Nga}^{1}$}

\section{TÓM TẮT}

Hôi chứng thân hư (HCTH) là bênh lý câu thận hay gặp nhất ở trẻ em với tỉ lệ mới mắc hàng năm là 2 7/100000 trẻ trên tổng tỉ lệ mắc bênh là $16 / 100000$ trẻ. Tại Việt Nam (1981-1990) có 1414 trẻ mắc HCTH nhập Bênh viên Nhi Trung ương, chiếm $46,6 \%$ tổng số bệnh nhân cửa Khoa Thận - Tiết niệu, trong đó 1358 trẻ được chẩn đoán HCTHH tiên phát $(91,0 \%)$. Theo y văn, những trẻ mắc HCTH có sự tác động phá hủy mô

1 Viện Đào tạo Răng Hàm Mặt-Trường Đại học Y Hà Nội 2Trường Đại hoc Y Hà Nôi

Chịu trách nhiệm chính: Lương Minh Hằng

Email: minhhang@hmu.edu.vn

Ngày nhận bài: 3.3.2021

Ngày phản biên khoa hoc: 22.4.2021

Ngày duyệt băi: 29.4.2021 quanh răng khi sử dụng kéo dài các loại thuốc trong điều trị bệnh. Ngoài ra, sự nhập viện thường xuyên và chế độ ăn uống riêng biệt cững ảnh hưởng đến việc chăm sóc vệ sinh răng miệng làm tăng tỉ lệ bệnh quanh răng ở trẻ. Nghiên cứu này nhằm mục đích mô tả thực trang bênh quanh răng và mối liên quan giữa bệnh và HCTH tiên phát ở trẻ em tại bệnh viện Nhi Trung ương. Phương pháp nghiên cứu mô tả cắt ngang được thực hiện ở 407 trẻ). Kết quả nghiên cứu cho thấy đa sổ trẻ viêm lơi và phì đai lợi đô 1 , cao răng gặp nhiều nhất ở trẻ 13-18 tuổi, có mối liên quan giữa thời gian mắc bênh, số lần tái phát, thể bệnh, việc sử dụng loại thuốc điêu trị và bệnh viêm lợi, phì đại lợi ở nhóm đối tướng nghiên cứu.

Tư khóa: hội chứng thận hư tiên phát, bệnh quanh răng, viêm lị̂i, lợi phì đại, cao răng, mối liên quan.

\section{SUMMARY}




\section{PERIODONTAL DISEASES AND RELATED FACTORS IN CHILDREN WITH PRIMARY NEPHROTIC SYNDROME}

Nephrotic syndrome (NS) is the most common glomerular disease in children with an annual incidence rate of $2-7 / 100,000$ children out of a total morbidity rate of $16 / 100,000$. In Vietnam (19811990), 1414 children with NS were admitted to the National Hospital of Pediatrics, accounting for $46,6 \%$ of the total number of patients in the Department of Nephrology - Urology, of which 1358 children were diagnosed with primary NS $(91,0 \%)$. According to the literature, patients with nephrotic syndrome have the effect of destroying hard tissue and surrounding parts after havingused drugs in a long-term treatment. In addition, regular hospitalization and specific diet also affect the care and prevention of oral diseases. This study aims to describe the periodontis diseases of children with primary nephrotic syndrome and some related factors at the National Hospital of Pediatrics. The method of cross-sectional descriptive studies was performed in a group of children diagnosed as primary nephrotic (407 children). Results of research as follow: the majority of children with gingivitis and hypertrophic gingivitis, tartar most commonly seen in children 13-18 years old, there is a relationship between the duration of the disease, the number of relapses, the form of the disease, the history of the disease use of drugs to treat gingivitis and gingivitis, hypertrophic gingivitis in the study group.

Keywords: nephrotic syndrome, gingivitis, hypertrophic gingivitis, tartar.

\section{I. ĐẶT VẤN ĐỀ}

Hội chứng thận hư (HCTH) là bệnh lý cầu thận hay gặp nhất ở trẻ em với tỉ lệ mới mắc hàng năm là $2-7 / 100000$ trẻ trên tổng tỉ lệ mắc bệnh là 16/100000 trẻ1. Tại Việt Nam, chưa có nhiều số liệu về tỉ lệ mới mắc hàng năm của HCTH, tuy nhiên theo số liệu nghiên cứu trong 10 năm từ 1981 đến 1990, có 1414 trẻ mắc HCTH nhập Bệnh viện Nhi Trung ương, chiếm 46,6\% tổng số bệnh nhân của Khoa Thận - Tiết niệu, trong đó 1358 trẻ được chẩn đoán $\mathrm{HCTH}$ tiên phát $(91,0 \%)$ và $4,0 \%$ trẻ là $\mathrm{HCTH}$ thứ phát 2. Theo y văn, những bệnh nhân mắc HCTH có sự tác động phá hủy mô cứng và các tổ chức quanh răng khi sử dụng kéo dài các loại thuốc trong điều trị bệnh ${ }^{3,4}$. Ngoài ra, sự nhập viện thường xuyên và chế độ ăn uống riêng biệt cũng ảnh hưởng đến việc chăm sóc và phòng ngừa các bệnh lý răng miệng. ${ }^{5}$ Babu và Jana (2014) ${ }^{6}$, Angelova và CS (2017) ${ }^{5}$ Güzel và CS (2018) ${ }^{7}$ đều cho kết quả trẻ mắc HCTH có tỉ lệ viêm lợi cao hơn so với trẻ bình thường, thường mắc tình trạng viêm lợi trung bình, và có $16,5 \%$ trẻ bị viêm lợi phì đại theo nghiên cứu của Weraarchakul và CS (2014) tại Thái Lan ${ }^{8}$. Ở Việt Nam, theo nghiên cứu của Phạm Thị Phượng
$(2017)^{9}:$ 90,7\% trẻ mắc HCTH tiên phát có viêm lợi, $78,2 \%$ trẻ dùng cyclosporin có phì đại lợi; $85,6 \%$ trẻ có cao răng. Trên thế giới có nhiều nghiên cứu về những ảnh hưởng của bệnh thận mạn tính đến bệnh quanh răng trên trẻ em trong những năm gần đây, nhưng vẫn còn ít nghiên cứu về mối liên quan này trên trẻ mắc HCTH tiên phát, đặc biệt ở Việt Nam mới chỉ có một nghiên cứu về vấn đề này. Với mong muốn đóng góp một phần số liệu để xây dựng bức tranh về bệnh quanh răng và mối quan hệ giữa HCTH tiên phát và bệnh, đồng thời giúp định hướng cho công tác chăm sóc sức khỏe răng miênng ở trẻ em để tăng phần hiệu quả cho việc phòng ngừa và điều trị chúng tôi thực hiện đề tài mô tả "Bệnh quanh rằng và một số yếu tố liên quan ở trẻ mắc hội chứng thận hư tiên phát".

\section{II. ĐỐI TƯỢNG VÀ PHƯƠNG PHÁP NGHIÊN CỨU}

1. Đối tượng nghiên cứu. Trẻ em được chẩn đoán hội chứng thận hư tiên phát tại khoa Thận - Lọc máu bệnh viên Nhi trung ương với những tiêu chuẩn chẩn đoán của ISKDC (International study of Kidney diseases in Children):

- Protein niệu $\geq 50 \mathrm{mg} / \mathrm{kg} / 24$ giờ

- Protein máu $<56 \mathrm{~g} / \mathrm{l}$

- Albumin máu $<25 \mathrm{~g} / \mathrm{l}$.

\section{Phương pháp nghiên cứu} mô tả

Thiết kế nghiên cứu: Nghiên cứu cắt ngang

Cỡ mẫu, chọn mẫu. Theo công thức tính ước tính cõ mẫu cho một tỉ lệ trong cộng đồng

$$
n=Z_{1-\alpha / 2}^{2} \frac{p \cdot(1-p)}{d^{2}}
$$

- n: cõ̃ mẫu tối thiểu cần có.

- Z1-a/2: hệ số giới hạn tin cậy, với a=0,05 ta có $\mathrm{Z} 1-\mathrm{a} / 2=1,96$

0,05

- d: khoảng sai lệch mong muốn, chọn $d=$

- p: tỉ lệ viêm lợi phì đại ở trẻ mắc bệnh hội chứng thân hư tiên phát của tác giả Phạm Thị Phượng và cộng sự $\mathrm{p}=0,782$ ' .

- Cõ̃ mẫu nghiên cứu sau khi áp dụng công thức: $n=262$ trẻ em

Trên thực tế chúng tôi đã khám và thu thập dữ liêu của 407 trẻ

Thu thập thông tin: Gửi thư xin ý kiến đồng ý tham gia nghiên cứu cho trẻ và gia đình. Gửi bộ câu hỏi phỏng vấn đền phụ huynh của trẻ để thu thập thông tin về cá nhân, đặc điểm bênh, thói quen vệ sinh răng miệng, thói quen ăn uống của đối tượng nghiên cứu. 
Tiêu chuẩn đánh giá: Phương pháp đánh giá vệ sinh răng miệng đơn giản OHI-S của Green và Vermillion (1964) gồm có hai chỉ số Chỉ số cặn bám đơn giản (DI-S) và chỉ số cao răng (CI-S)

Phương pháp đánh giá lợi GI theo Loe và Silness (1963)

Phương pháp đánh giá phì đại lợi GOI theo McGaw và cộng sự (1988)

\section{Thời gian địa điểm nghiên cứu}

Thời gian nghiên cứu: Từ tháng 4/2019 đến tháng $1 / 2021$

Địa điểm nghiên cứu: Khoa thận - lọc máu Bệnh viện Nhi Trung Ương Hà Nội, Số 18/879 Đường La Thành, Láng Thượng, Đống Đa, Hà Nội.

4. Đạo đức nghiên cứu. Nghiên cứu đã được chấp thuận bởi Hội đồng đạo đức trong nghiên cứu y sinh học của Trường Đại học $Y$ Hà
Nội số NCS17/ĐHYHN-HĐĐĐ ngày 27 tháng 03 năm 2019.

\section{KẾT QUẢ NGHIÊN CỨU}

1. Đăcc điểm chung của đối tượng nghiên cứu. Theo kết quả nghiên cứu thì đa sỗ bệnh nhân là nam giới (309 trường hợp chiếm 75,6\%); số lượng bệnh nhân ở độ tuổi 7-12 chiếm đa số (211 trẻ chiếm $51,8 \%$ ). Về thời gian mắc bệnh: đa số các bệnh nhân trong nghiên cứu mắc bệnh 1-5 năm (195/407 trường hợp, chiếm tỉ lệ $47,9 \%)$. Về thể bệnh: đa số các bệnh nhân trong nghiên cứu có thể bệnh kháng thuốc (239/407 trường hợp). Về tình trạng điều trị: đa số các bệnh nhân đang điều trị (330/407 trường hợp). Có 191/407 trường hợp bị tái phát từ 3 lần trở lên chiếm 46,9\%.

2. Đặc điểm bệnh quanh răng ở trẻ mắc hội chứng thận hư tiên phát

Bảng 1. Phân độ viêm lợi, phì đại lợi theo nhóm tuối

\begin{tabular}{|c|c|c|c|c|c|c|c|c|}
\hline \multirow{3}{*}{ Nhóm tuổi } & \multicolumn{4}{|c|}{ Viếm lợi } & \multicolumn{4}{|c|}{ Phì đại lợi } \\
\hline & Độ 0 & Đố 1 & Đố 2 & Độ 3 & Độ 0 & Độ 1 & Đố 2 & Độ 3 \\
\hline & $n(\%)$ & $\mathrm{n}(\%)$ & $n(\%)$ & $n(\%)$ & $n(\%)$ & $n(\%)$ & $n(\%)$ & $n(\%)$ \\
\hline $\begin{array}{l}3-6 \text { tuối } \\
(n=122)\end{array}$ & $\begin{array}{c}67 \\
(54,9)\end{array}$ & $\begin{array}{c}45 \\
(36,9)\end{array}$ & $8(6,6)$ & $2(1,6)$ & $\begin{array}{c}119 \\
(97,5)\end{array}$ & $3(2,5)$ & 0 & 0 \\
\hline $\begin{array}{l}\text { 7-12 tuối } \\
(\mathrm{n}=211)\end{array}$ & $\begin{array}{c}63 \\
(29,8)\end{array}$ & $\begin{array}{c}112 \\
(53,1)\end{array}$ & $\begin{array}{c}28 \\
(13,3)\end{array}$ & $8(3,8)$ & $\begin{array}{c}179 \\
(84,8)\end{array}$ & $\begin{array}{c}23 \\
(10,9)\end{array}$ & $\begin{array}{c}7 \\
(3,3)\end{array}$ & $2(1,0)$ \\
\hline $\begin{array}{c}13-18 \text { tuối } \\
(n=74)\end{array}$ & $\begin{array}{c}17 \\
(23,0)\end{array}$ & $\begin{array}{c}40 \\
(54,1)\end{array}$ & $\begin{array}{c}12 \\
(16,2)\end{array}$ & $5(6,7)$ & $\begin{array}{c}59 \\
(79,7)\end{array}$ & $\begin{array}{c}12 \\
(16,2)\end{array}$ & $\begin{array}{c}2 \\
(2,7)\end{array}$ & $1(1,4)$ \\
\hline $\begin{array}{c}\text { Tống } \\
(n=407)\end{array}$ & $\begin{array}{c}147 \\
(36,1)\end{array}$ & $\begin{array}{c}197 \\
(48,4)\end{array}$ & $\begin{array}{c}48 \\
(11,8)\end{array}$ & $\begin{array}{c}15 \\
(3,7)\end{array}$ & $\begin{array}{c}357 \\
(87,7)\end{array}$ & $\begin{array}{c}38 \\
(9,3)\end{array}$ & $\begin{array}{c}9 \\
(2,2)\end{array}$ & $\begin{array}{c}3 \\
(0,7)\end{array}$ \\
\hline p (chi2 test) & & & & & & & & \\
\hline
\end{tabular}

Phân đô viêm lợi và phì đại lơi theo nhóm tuổi được thể hiên qua Bảng 1. Đa số các bênh nhân trong nghiên cứu có phân độ viểm lợi độ 1 (48,4\%). Đa số bệnh nhân không phì đại lợi $(87,7 \%)$. Trong số bệnh nhân phì đại lợi thì chủ yếu là phì đại lợi độ 1.

Bảng 2. Phân bố cao rằng theo nhóm tuổi (Cí-s)

\begin{tabular}{|c|c|c|c|c|c|c|c|c|}
\hline \multirow{2}{*}{ Nhóm tuổi } & Không có cao răng & Cao răng độ 1 & \multicolumn{2}{c|}{ Cao răng độ 2 } & \multicolumn{2}{c|}{ Cao răng độ 3 } \\
\cline { 2 - 9 } & $\mathrm{n}$ & $\%$ & $\mathrm{~N}$ & $\%$ & $\mathrm{n}$ & $\%$ & $\mathrm{n}$ & $\%$ \\
\hline 3-6 tuối $(\mathrm{n}=122)$ & 86 & 70,5 & 14 & 11,5 & 18 & 14,7 & 4 & 3,3 \\
\hline $7-12$ tuô̂i $(\mathrm{n}=211)$ & 98 & 46,4 & 49 & 23,2 & 43 & 20,4 & 21 & 10,0 \\
\hline $13-18$ tuối $(\mathrm{n}=74)$ & 20 & 27,0 & 21 & 28,4 & 18 & 24,3 & 15 & 20,3 \\
\hline Tống (n=407) & $\mathbf{2 0 4}$ & $\mathbf{5 0 , 1}$ & $\mathbf{8 4}$ & $\mathbf{2 0 , 7}$ & $\mathbf{7 9}$ & $\mathbf{1 9 , 4}$ & $\mathbf{4 0}$ & $\mathbf{9 , 8}$ \\
\hline P (chi2 test) & \multicolumn{8}{|c|}{$\mathbf{0 , 0 0 0}$} \\
\hline
\end{tabular}

Trong Bảng 2 cho thấy bệnh nhân có cao răng chiếm 49,9\% trong tống số bệnh nhân, đa số các bênh nhân có cao răng đô 1 và 2 lần lượt là $20,7 \%$ và $19,4 \%$. Chỉ có $9,8 \%$ bênh nhân có cao răng độ 3. Tỉ lệ bệnh nhân khổng có cao răng ở nhóm tuổi 3-6 chiếm tỉ lệ cao nhất (70,5\%). Tỉ lệ bệnh nhân có cao răng độ 2 và độ 3 gặp nhiêu nhất ở nhóm tuổi 13-18 tuổi.

3. Mối liên quan giữa bệnh quanh răng và hội chứng thận hư tiên phát

Bảng 3. Liên quan giữa viêm lợi và đặc điểm HCTH tiên phát

\begin{tabular}{|c|c|c|c|c|c|c|}
\hline \multirow{2}{*}{\multicolumn{2}{|c|}{ Một số đặc điểm về HCTHTP }} & \multicolumn{2}{|c|}{ Viêm Iợi } & \multicolumn{2}{|c|}{ Không viêm lợi } & \multirow{2}{*}{$\begin{array}{c}\text { OR } \\
\text { (95\% CI) }\end{array}$} \\
\hline & & $\mathbf{N}$ & $\%$ & $n$ & $\%$ & \\
\hline \multirow{2}{*}{ Giới } & Nam & 199 & 64,4 & 110 & 35,6 & 1 \\
\hline & Nữ & 61 & 62,2 & 37 & 37,8 & $1,10(0,66-1,80)$ \\
\hline \multirow{3}{*}{$\begin{array}{c}\text { Thời gian mắc } \\
\text { bệnh }\end{array}$} & $\leq 1$ năm & 59 & 49,6 & 60 & 50,4 & 1 \\
\hline & 1-5 năm & 132 & 67,7 & 63 & 32,3 & $2,13(1,33-3,40)$ \\
\hline & $>5$ năm & 69 & 74,2 & 24 & 25,8 & $2,92(1,63-5,26)$ \\
\hline
\end{tabular}


TẠP CHÍ Y HỌC VIỆT NAM TẬP 502 - THÁNG 5 - SỐ 1 - 2021

\begin{tabular}{|c|c|c|c|c|c|c|}
\hline \multirow{3}{*}{ Thể bệnh } & Nhảy cảm corticoid & 44 & 55,7 & 35 & 44,3 & 1 \\
\cline { 2 - 7 } & Phụ thuộc corticoid & 57 & 65,5 & 30 & 34,5 & $1,51(0,81-2,83)$ \\
\cline { 2 - 7 } & Kháng thuốc corticoid & 157 & 65,7 & 82 & 34,3 & $1,52(0,91-2,56)$ \\
\hline \multirow{2}{*}{$\begin{array}{c}\text { Liều } \\
\text { prednisolon }\end{array}$} & Ngưng thuốc & 50 & 64,9 & 27 & 35,1 & 1 \\
\cline { 2 - 7 } & Đang điêuu trị & 210 & 63,6 & 120 & 36,4 & $1,06(0,61-1,86)$ \\
\hline \multirow{2}{*}{$\begin{array}{c}\text { Thuốc điều trị } \\
\text { kết hợp }\end{array}$} & Không dùng thuốc kết hợp & 104 & 61,9 & 64 & 38,1 & 1 \\
\cline { 2 - 7 } & Dùng Cyclosporin/ Cellcept & 156 & 65,3 & 83 & 34,7 & $0,86(0,56-1,33)$ \\
\hline \multirow{3}{*}{$\begin{array}{c}\text { Số lần tái } \\
\text { phát }\end{array}$} & Bị lần đâuu & 53 & 57,6 & 39 & 42,4 & 1 \\
\cline { 2 - 7 } & $1-3$ lần & 75 & 60,5 & 49 & 39,5 & $1,12(0,65-1,95)$ \\
\cline { 2 - 7 } & 3-6 lần & 39 & 60,0 & 26 & 40,0 & $1,10(0,58-2,11)$ \\
\cline { 2 - 7 } & Tái phát >6 lần & 93 & 73,8 & 33 & 26,2 & $2,07(1,17-3,68)$ \\
\hline
\end{tabular}

Mối liên quan giữa viêm lợi và các đặc điếm của HCTH tiên phát được thế hiện qua Bảng 3 : Nhóm bệnh nhân có thời gian điều trị trên 5 năm có nguy cơ bị viêm lợi gấp 2,92 lần nhóm bệnh nhân có thời gian điêu trị từ 1 năm trở xuống. Sự khác biệt có ý nghĩa thống kê. Nhóm bệnh nhân có số lần tái phát trên 6 lần có nguy cơ bị viêm lợi gấp 2,07 lần so với nhóm bệnh nhân bị lẩn đầu. Có sự khác biệt có ý nghĩa thống kê giữa số lần tái phát và tình trạng viêm lợi.

\section{Bảng 4. Mối liên quan giữa phi đại lợi và đặc điểm HCTH tiên phát}

\begin{tabular}{|c|c|c|c|c|c|c|c|}
\hline \multirow{2}{*}{\multicolumn{2}{|c|}{ Một số đặc điểm về HCTHTP }} & \multicolumn{2}{|c|}{ Phì đại lợi } & \multicolumn{2}{|c|}{$\begin{array}{c}\text { Không phì } \\
\text { đại lợi }\end{array}$} & \multicolumn{2}{|r|}{$\begin{array}{c}\text { OR } \\
(95 \% \mathrm{CI})\end{array}$} \\
\hline & & $\mathbf{n}$ & $\%$ & $\mathbf{n}$ & $\%$ & & \\
\hline \multirow{2}{*}{ Giới } & Nam & 40 & 12,9 & 269 & 87,1 & & 1 \\
\hline & Nữ & 10 & 10,2 & 88 & 89,8 & & $31(0,61-3,06)$ \\
\hline \multirow{3}{*}{$\begin{array}{l}\text { Thời gian } \\
\text { mắc bệnh }\end{array}$} & $\leq 1$ năm & 4 & 3,4 & 115 & 96,6 & & 1 \\
\hline & 1-5 năm & 27 & 13,9 & 168 & 86,1 & & $62(1,57-13,56)$ \\
\hline & >5 năm & 19 & 20,4 & 74 & 79,6 & & $38(2,42-22,56)$ \\
\hline \multirow{3}{*}{ Thể bệnh } & Nhảy cảm corticoid & 2 & 2,5 & 77 & 97,5 & & 1 \\
\hline & Phụ thuộc corticoid & 4 & 4,6 & 83 & 95,4 & & $86(0,33-10,42)$ \\
\hline & Kháng thuốc corticoid & 44 & 18,4 & 195 & 81,6 & & $69(2,06-36,72)$ \\
\hline \multirow{4}{*}{$\begin{array}{l}\text { Liều } \\
\text { prednisolon } \\
\text { Thuốc điêuu } \\
\text { trị kết hợp }\end{array}$} & Ngưng thuốc & 12 & 15,6 & 65 & 84,4 & & 1 \\
\hline & Đang điều trị & 38 & 11,5 & 292 & 88,5 & &, $42(0,64-2,96)$ \\
\hline & Không dùng thuốc kết hợp & 6 & 3,6 & 162 & 96,4 & & 1 \\
\hline & Dùng Cyclosporin/ Cellcept & 44 & 18,4 & 195 & 81,6 & & $09(2,49-17,88)$ \\
\hline \multirow{4}{*}{$\begin{array}{l}\text { Số lần tái } \\
\text { phát }\end{array}$} & Bị lần đầu & 2 & 2,2 & 90 & 97,8 & & 1 \\
\hline & 1 - 3 lần & 13 & 10,5 & 111 & 89,5 & & $27(1,16-23,96)$ \\
\hline & 3-6 lần & 6 & 9,2 & 59 & 90,8 & & $58(0,89-23,44)$ \\
\hline & Tái phát >6 lần & 29 & 23,0 & 97 & 77,0 & &, $45(3,12-58,01)$ \\
\hline \multicolumn{8}{|c|}{ 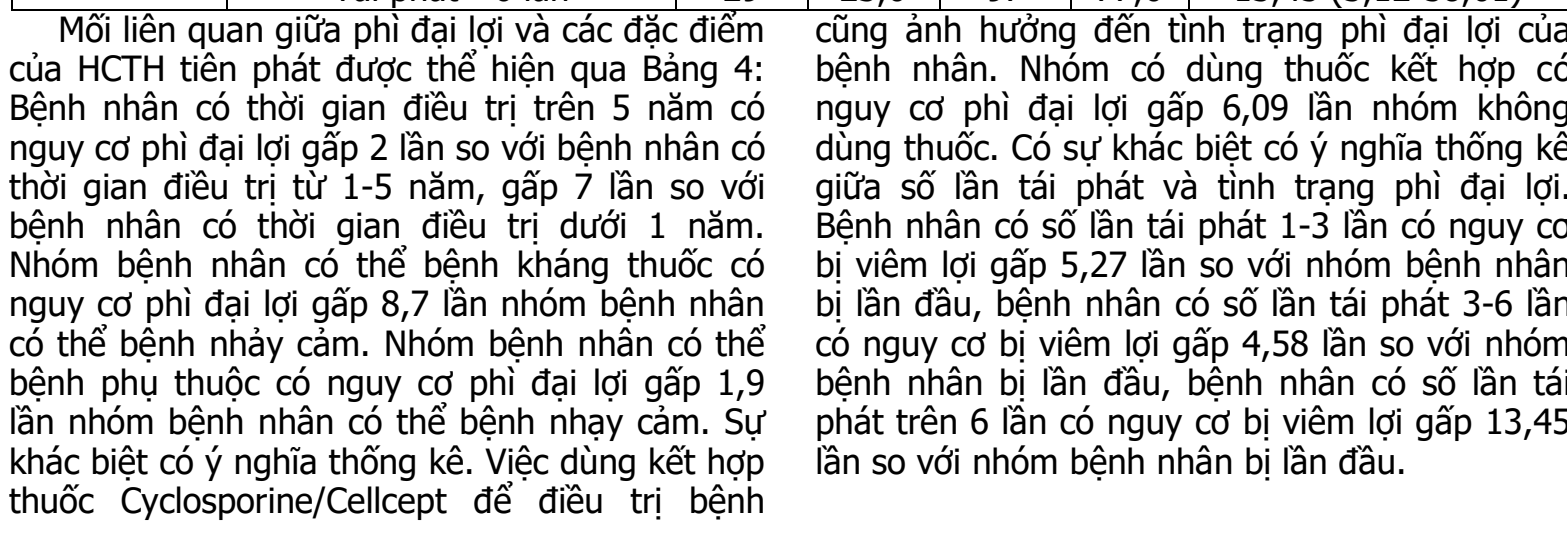 } \\
\hline \multicolumn{8}{|c|}{ Bảng 5. Môi liên quan giữa cao răng và đặc điểm HCTH tiên phát } \\
\hline \multirow{2}{*}{\multicolumn{2}{|c|}{ Một số đặc điểm về HCTHTP }} & \multirow{2}{*}{\multicolumn{2}{|c|}{\begin{tabular}{|c|c|}
\multicolumn{2}{|c|}{ Cao răng } \\
n
\end{tabular}}} & \multicolumn{3}{|c|}{ Không cao răng } & \multirow{3}{*}{$\begin{array}{c}\text { OR } \\
(95 \% \mathrm{CI})\end{array}$} \\
\hline & & & & $\mathbf{n}$ & & & \\
\hline Giới & Nam & 159 & 51,5 & 150 & & & \\
\hline
\end{tabular}


VIETNAM MEDICAL JOURNAL N01 - MAY - 2021

\begin{tabular}{|c|c|c|c|c|c|c|}
\hline & Nũ̃ & 44 & 44,9 & 54 & 55,1 & $1,30(0,80-2,11)$ \\
\hline \multirow{3}{*}{$\begin{array}{l}\text { Thời gian } \\
\text { mắc bệnh }\end{array}$} & $\leq 1$ năm & 41 & 34,5 & 78 & 65,5 & 1 \\
\hline & 1-5 năm & 93 & 47,7 & 102 & 52,3 & $1,73(1,08-2,78)$ \\
\hline & $>5$ năm & 69 & 74,2 & 24 & 25,8 & $5,47(3,01-9,96)$ \\
\hline \multirow{3}{*}{ Thể bệnh } & Nhảy cảm corticoid & 49 & 62,0 & 30 & 38,0 & 1 \\
\hline & Phụ thuộc corticoid & 38 & 43,7 & 49 & 56,3 & $0,48(0,26-0,88)$ \\
\hline & Kháng thuốc corticoid & 114 & 47,7 & 125 & 52,3 & $0,56(0,33-0,94)$ \\
\hline \multirow{2}{*}{$\begin{array}{c}\text { Liều } \\
\text { prednisolon }\end{array}$} & Ngưng thuốc & 39 & 50,7 & 38 & 49,3 & 1 \\
\hline & Đang điều trị & 164 & 49,7 & 166 & 50,3 & $1,04(0,61-1,76)$ \\
\hline \multirow{2}{*}{$\begin{array}{l}\text { Thuốc điều } \\
\text { trị kết hợp }\end{array}$} & Không dùng thuốc kết hợp & 90 & 53,6 & 78 & 46,4 & 1 \\
\hline & Dùng Cyclosporin/ Cellcept & 113 & 47,3 & 126 & 52,7 & $1,29(0,85-1,95)$ \\
\hline \multirow{4}{*}{$\begin{array}{l}\text { Số lần tái } \\
\text { phát }\end{array}$} & Bị lần đâu & 61 & 66,3 & 31 & 33,7 & 1 \\
\hline & 1 - 3 lân & 46 & 37,1 & 78 & 62,9 & $0,30(0,17-0,53)$ \\
\hline & 3-6 lần & 38 & 58,5 & 27 & 41,5 & $0,72(0,37-1,38)$ \\
\hline & Tái phát >6 lần & 58 & 46,0 & 68 & 54,0 & $0,43(0,25-0,76)$ \\
\hline
\end{tabular}

Mối liên quan giữa chỉ số cao răng và các đặc điểm của HCTH tiên phát được thể hiện qua Bảng 5: Bệnh nhân có thời gian điều trị trên 5 năm có nguy cơ bị cao răng gấp 5 lần bệnh nhân có thời gian điêu trị từ 5 năm trở xuống. Sự khác biệt có ý nghĩa thống kê. Bệnh nhân có thể bệnh phụ thuộc và thể bệnh kháng thuốc có nguy cơ bị cao răng bằng một nửa so với lần nhóm bệnh nhân có thể bệnh nhạy cảm. Sự khác biệt có ý nghĩa thống kê. Có sự khác biệt có ý nghĩa thống kê giữa số lần tái phát và tình trạng cao răng nhưng đều thấp hơn so với bệnh nhân mắc bệnh lần đầu.

\section{BÀN LUẬN}

Sau khi tiến hành thu thập thông tin, khám răng miệng cho trẻ được chẩn đoán là mắc HCTH tiên phát tại Khoa Thận-lọc máu Bệnh viện Nhi Trung ương, nghiên cứu xác định được 407 trẻ đưa vào nghiên cứu. Trong nghiên cứu này, trẻ nam có tỉ lệ mắc hội HCTH tiên phát cao hơn nữ (309 so với 98), kết quả này cũng tương tự như các nghiên cứu khác thực hiện ở Việt Nam cũng như nước ngoài về đặc điểm dịch tê̂̃ mắc hội chứng thận hư gặp ở trẻ trai nhiều hơn trẻ gái, tỷ lệ trai/gái là $3 / 1^{5}$. Về thể bệnh: đa số các bệnh nhân trong nghiên cứu có thể bệnh kháng thuốc (239/407 trường hợp) và có 191/407 trường hợp bị tái phát từ 3 lần trở lên chiếm $46,9 \%$, tình trạng kháng thuốc và tái phát nhiều lần này sẽ khiến trẻ phải dùng thêm nhiều thuốc ức chế miễn dịch khác để điều trị, tác dụng phụ của những thuốc này là gây nguy cớ nhiếm trùng cao, gây ra phì đại lợi cho trè, tăng nguy cơ mắc các bệnh răng miệng trong thời gian điều trị bệnh toàn thân.

Bảng 1 cho thấy tỉ lệ viêm lợi chiếm $63,9 \%$ trong đó nhóm 13 - 18 tuổi có tỉ lệ cao nhất
$(77,0 \%)$ nhưng đa số trẻ có viêm lợi mức đô 1 $(48,4 \%)$. Hầu hết các nghiên cứu chỉ ra rằng tỉ lệ bệnh viêm lợi ở trẻ mắc hội chứng thận hư đều cao hơn so với trẻ khỏe mạnh. Mặc dù vậy, các tác giả ${ }^{5-8}$ đều đồng tình rẳng ít khi hoặc không biểu hiện nặng nề hoặc chỉ biểu hiện ở mức trung bình trên trẻ mắc HCTH. Các tác giả cũng nhận thấy một mối tương quan thuận giữa tình trạng lợi và chỉ số cặn bám và cao răng. Có 50/407 trẻ (chiếm 12,3\%) bị phì đại lợi nhưng chủ yếu là phì đại lợi độ 1 . Kết quả này phù hợp với nhận định của tác giả Wright $\mathrm{G}$ và $\mathrm{CS}$ cho rằng phì đại lợi là một tác dụng phụ khi uống Cyclosporin $A$ và ti lệ phì đại lợi do dùng thuốc là từ $8 \%$ đến $100 \%$. Mặc dù tỉ lể viêm lợi và lợi phì đại ở trẻ mắc HCTH tiên phát khá cao nhưng hầu hết cha me trẻ chưa có kiến thức về bênh răng miệng, chỉ đưa trẻ đi khám răng hàm mặt khi con bị đau và chưa hiểu mối liên quan giữa bệnh răng miệng và bệnh toàn thân mà trẻ đang mắc phải. Kết quả của chúng tôi thấp hơn nghiên cứu của Phạm Thị Phượng và $\mathrm{CS}^{9}$ và một số nghiên cứu trên những trẻ mắc bệnh lý thận mạn tính. Sự khác biệt này có thể do đối tượng nghiên cứu của chúng tôi khác độ tuổi của các tác giả khác và nghiên cứu của chúng tôi về thời gian dùng thuốc Cyclosporin ngắn hơn, do nguyên nhân gây ra phì đại lợi bao gồm tác động của thuốc, tình trạng mảng bám, sự nhạy cảm của các nguyên bào sợi và các yếu tố di truyền.

Bảng 2 cho biết tî lệ cao răng chiếm 49,9\% tổng số bệnh nhân, đa số các bệnh nhân có cao răng độ 1 và 2 lần lượt là $20,7 \%$ và $19,4 \%$. Trong nghiên cứu của chúng tôi thì tỉ lệ cao răng của trẻ mắc HCTP tiên phát ngang với trẻ bình thường tại Việt Nam. Kết quả của chúng tôi thấp hơn kết quả của Phạm Thị Phượng và $\mathrm{CS}^{9}$, Babu và $\mathrm{CS}{ }^{6}$ đều nhận thấy rằng trẻ mắc bệnh thận 
có nhiều cao răng, nhất là mặt lưỡi của răng cửa hàm dưới, Nguyên nhân là do sự thay đổi lượng canxi, phốtpho, magiê, oxalat, urê trong nước bot. Lắng đọng canxi-phốtpho hoăc canxi-oxalat và hình thành cao răng có thể do sự tăng $\mathrm{pH}$ nước bọt. Ngoài ra, lượng magiê trong nước bọt giảm nhưng urê và phốtpho trong nước bọt lại tăng dẫn đến tăng tỉ lệ cao răng cho bệnh nhân.

Bảng 3 cho thấy mối liên quan giữa đặc điểm của hội chứng thận hư với tình trạng viêm lợi của nhóm đối tượng nghiên cứu: Nhóm bệnh nhân có thời gian điều trị trên 5 năm có nguy cơ bị viêm lợi gấp 2,92 lần nhóm bệnh nhân có thời gian điều trị từ 1 năm trở xuống $(\mathrm{OR}=2,92$ và $95 \%$ CI là $1,63-5,26)$. Nhóm bệnh nhân có số lần tái phát trên 6 lần có nguy cơ bị viêm lợi gấp 2,07 lần so với nhóm bênh nhân bi lần đầu (OR= $2,07$ và $95 \%$ CI là $1,17-3,68)$. Việc điều trị bệnh lâu dài và tái phát thường xuyên làm trẻ và gia đình trẻ tập trung quan tâm đến việc điều trị bênh đang mắc phải, mà ít hoắc khồng quan tầm đến chăm sóc răng miệng cũ̃ng như không được giáo dục chăm sóc răng miệng đúng cách làm gia tăng tích tụ mảng bám gây viêm lợi. Tái phát bênh nhiều lần dẫn đến việc dùng thuốc thời gian dài, dễ gặp phải tác dụng phụ của thuốc gây nguy cơ nhiễm trùng cao, cũng có thể do khô miệng do tác dụng phụ của thuốc điều chỉnh huyết áp làm tăng nguy cơ viêm lợi.

Bảng 4 cho thấy liên quan giữa đặc điểm của hội chứng thận hư với tình trạng phì đại lợi của nhóm đối tượng nghiên cứu: Bệnh nhân có thời gian điều trị trên 5 năm có nguy cơ phì đại lợi gấp 2 lần so với bệnh nhân có thời gian điều trị từ 1-5 năm, gấp 7 lần so với bệnh nhân có thời gian điều trị dưới 1 năm. Nhóm bệnh nhân có thể bênh kháng thuốc có nguy cơ phì đai lợi gấp 8,7 lần nhóm bệnh nhân có thể bệnh nhảy cảm. Việc dùng kết hợp thuốc Cyclosporine/Cellcept để điêu trị bệnh cũng ảnh hưởng đến tình trạng phì đại lợi của bênh nhân. Nhóm có dùng thuốc kết hợp có nguy cơ phì đại lợi gấp 6,09 lần nhóm không dùng thuốc. Bệnh nhân có số lần tái phát 1-3 lần có nguy cơ bị viêm lợi gấp 5,27 lần so với nhóm bênh nhân bi lần đầu, bệnh nhân có số lần tái phát 3-6 lần có nguy cơ bị viêm lợi gấp 4,58 lần so với nhóm bệnh nhân bị lần đầu, bệnh nhân có số lần tái phát trên 6 lần có nguy cờ bị viêm lợi gấp 13,45 lần so với nhóm bệnh nhân bị lần đâu. Điêu này chỉ ra tác dụng phụ khi dùng thuốc ức chế miển dịch kết hợp để điều trị cho trẻ kháng thuốc, trẻ đang trong thời gian dùng thuốc thì chiu tác dung phu phì đại lợi là rõ ràng nhất. Kết luận này đã được báo cáo trong rất nhiều nghiên cứu như trong nghiên cứu của Wright G, Welbury $R R$, Hosey $M T$ hay nghiên cứu của Suzanne D.A, DDS, MS Alton G.M và CS.

Mối liên quan giữa chỉ số cao răng và đặc điểm của HCTH tiên phát được thể hiên qua Bảng 5: Bệnh nhân có thời gian điều trị trên 5 năm có nguy cơ bị cao răng gấp 5 lần bệnh nhân có thời gian điêuu trị từ 5 năm trở xuống. Ngoài ra chưa thây mối quan hệ giữa tình trạng cao răng và thể bệnh, tình trạng sử dụng thuốc và số lần tái phát.

\section{KẾT LUÂN}

Qua nghiên cứu 407 trẻ mắc hội chứng thận hư tiên phát tại Khoa Thận- Lọc máu Bệnh viện Nhi Trung Ương chúng tôi rút ra một số kết luận như sau: Tỉ lệ trẻ mắc bệnh viêm lợi và viêm lợi phì đại cao. Yếu tố thời gian bị bệnh, số lần tái phát, thể bệnh và thuốc điêu trị bệnh có liên quan đến tình trạng viêm lợi, phì đại lợi có ý nghĩa thống kê. Các yếu tố khác chưa tìm thây mối quan hệ có ý nghĩa thống kê.

\section{TÀI LIỆU THAM KHẢO}

1. Eddy AA, Symons JM. Nephrotic syndrome in childhood. Lancet Lond Engl. 2003;362(9384):629639. doi:10.1016/S0140-6736(03)14184-0

2. Lê Nam Trà, Trân Đình Long, Đố Bích Hằng. Tình hình bếnh thận, tiết niệu của trẻ em được điều trị tại Viện Nhí 1981-1990. Kỷ Êu Công Trình Nhi Khoa. Published online 1994:161-162.

3. Blue $C$, Isringhausen $K$. Raising Oral Health Awareness Among Nephrology Nurses. 2011;85(2):7.

4. Mihalaş E, Matricala $L$, Chelmuş $A$, Gheţu $N$, Petcu A, Paşca S. The Role of Chronic Exposure to Amoxicillin/Clavulanic Acid on the Developmental Enamel Defects in Mice. Toxicol Pathol. 2016;44(1):61-70. doi:10.1177/ 0192623315610822

5. Angelova ST. Oral Health in Children Suffering from Pyelonephritis and Nephrotic Syndrome. J Healthc Hyg. 2017;1(1). Accessed March 12, 2020. https://www.imedpub.com/abstract/oral-health-inchildren-suffering-from-pyelonephritis-andnephrotic-syndrome-21261.html

6. Babu NSV, Jana S. Assessment of Oral Health Status in Children Suffering from Nephrotic Syndrome. 2014;2(2):5.

7. Ulu Güzel KG, Yilmaz D, Abacigil F, PİRİNÇCi் S. Oral Aspects in Children with Nephrotic Syndrome - ProQuest. Published 2018. Accessed March 31, 2020. https://search.proquest.com/ openview/abefb6b2e8f40fb85a157c5240e86aab/1? pq-origsite $=$ gscholar $\& \mathrm{cbl}=236264$.

8. Weraarchakul $W$, Weraarchakul $W$, Wisanuyotin S, Panamonta M. Enamel defect and gingival enlargement in pediatric patients with kidney disease at Srinagarind Hospital, Khon Kaen University, Thailand. J Med Assoc Thail Chotmaihet Thangphaet. 2014;97 Suppl 10:S75-81. 